\title{
Age-Based Faultlines and Perceived \\ Productive Energy: \\ The Moderation of \\ Transformational \\ Leadership
}

Small Group Research

$4 I$ (5) 593-620

(C) The Author(s) 2010

Reprints and permission: sagepub.com/journalsPermissions.nav DOI: I0.1I77/I0464964/0366307 http://sgr.sagepub.com

@SAGE

\section{Florian Kunze' and Heike Bruch'}

\begin{abstract}
This article addresses the role of age-based faultlines in relation to the perceived productive energy of work teams and transformational leadership as a potential moderator of this relationship. Based on social identity and social categorization theory, teams that have strong age-based faultinesdefined as age subgroup formation that is reinforced by internal alignment with other demographic characteristics (tenure and sex) - should show a lower level of perceived productive energy than do teams that have weak faultlines. In teams with high levels of perceived transformational leadership, this effect should be reversed. Study hypotheses were tested on a sample of 664 individuals in 72 teams from a multinational company. Results showed a marginally significant negative relationship between age-based faultlines and teams' productive energy, although the moderation effect of transformational leadership was found to be significant. These results point toward transformational leadership as a promising strategy for overcoming the negative effects of age-based faultlines in team settings.
\end{abstract}

\footnotetext{
'University of St. Gallen, St. Gallen, Switzerland
}

Corresponding Author:

Florian Kunze, University of St. Gallen, Dufourstr. 40a, St. Gallen 9000, Switzerland

Email:florian.kunze@unisg.ch 


\section{Keywords}

faultlines, transformational leadership, productive energy, moderation, demographic change, team

\section{Introduction}

Increasing workforce diversity is an important challenge for companies, especially given the fact that effective team work is a crucial success factor for many organizations today (e.g., Kirkman, Rosen, Tesluk, \& Gibson, 2004). In many Western developed countries, this challenge is intensified because of the projected aging of the population and decline in actual population numbers over the coming decades, labeled as the demographic change (European Commission, 2006; United Nations, 2005). Because of a growing lack of skilled junior employees, companies will be urged to keep more older personnel and hence forced to deal with a dramatically aging and age diverse workforce (e.g., Dychtwald, Erickson, \& Morison, 2004; Tempest, Barnatt, \& Coupland, 2002). Already today, for example, just more than half of the 147-million-member workforce in the United States is 40 years or older, and until 2016, the number of workers aged 25 to 54 years will rise only slightly (2.4\%), whereas the workers aged 55 to 64 years are expected to climb by $36.5 \%$ (U.S. Bureau of Labor Statistics, 2008). As a consequence, more companies will have to develop concepts to integrate older workers productively into their mixed aged work teams. How to manage such age diverse teams will become a crucial factor for success and productivity, and managers in all kinds of organizations will need reliable insights on how to best lead and manage age heterogeneous teams.

Unfortunately for practitioners in companies, diversity research has shown largely mixed results for the effects of age diversity on work team processes and performance. Although some studies reported positive effects of age diversity on performance (e.g., Kilduff, Angelmar, \& Mehra, 2000), or no significant effects (e.g., Bunderson \& Sutcliffe, 2002; Simons, Pelled, \& Smith, 1999), most research has found negative effects of age diversity on team processes and performance (e.g., Ely, 2004; Leonard, Levine, \& Joshi, 2004; Timmerman, 2000). Similar contradictory findings have also been reported in studies of other diversity characteristics (e.g., Jackson, Joshi, \& Erhardt, 2003; van Knippenberg \& Schippers, 2007) and call for a more comprehensive approach to diversity research (Bezrukova, Jehn, Zanutto, \& Thatcher, 2009). Two recent advancements in this regard are the group faultine perspective (Lau \& Murnigham, 1998) and the identification of potential 
boundary conditions required to reap the benefits of group diversity (Lawrence, 1997; van Knippenberg \& Schippers, 2007).

The first recent advancement, the concept of group faultlines, refers to "hypothetical dividing lines that may split a group into subgroups based on one or more attributes" (Lau \& Murnigham, 1998, p. 328). Thus, diversity processes may not occur as a result of a single demographic attribute but as consequence of a bundle of demographic characteristics (Bezrukova et al., 1998; Lau \& Murnighan, 2005). If group members are divided into two distinct nonoverlapping subgroups based on different demographics (e.g., young, less experienced men and older, very experienced women), there is a strong group faultline (Lau \& Murnighan, 2005). Faultline strength is greatest when the internal alignment based on several characteristics is high and the alignment across several subgroups is low.

According to Shaw's (2004) specific definition, faultline strength can be assessed relative to each individual attribute in a group. That definition differs from others (e.g., Thatcher, Jehn, Zanutto, 2003) that only consider one general faultline in teams based on the equal assessment of all included criteria. In terms of age diversity in companies, it is interesting to know whether age-based subgroups turn into faultlines in relation to other demographic characteristics, such as tenure and sex. For example, even though they are divided by huge age differences (e.g., 25-50 years), team members might be cohesive, simply because they entered the company at the same time. The joint experience they had when they had started to work for the company might function as a social clue that may preclude faultline creation based on age differences.

Jackson et al. (2003) defined a major research gap in their review of the diversity literature as less than $5 \%$ of all diversity studies have addressed the question of whether the effects of one diversity dimension depend on the presence or absence of other dimensions. Therefore, investigating age-based subgroups, which have been neglected in empirical research so far, may lead to better understanding of the consequences of increasing age diversity in companies.

As the second recent advancement in the diversity literature, research has emerged that examined moderators that help groups to profit from diversity, following the debate triggered by Lawrence (1997) on the black box of organizational demography. For example, Jackson et al. (2003) list task characteristics, organizational culture, strategic context, and temporal context as the most researched factors. Other scholars have focused on identification processes as positive moderators in terms of age diversity, team processes, and outcomes (Roberge \& Van Dick, 2007). Others have considered team size, with an assumed positive moderation (Mullen, 1991; Mullen et al., 1991; 
Wegge, Roth, Neubach, Schmidt, \& Kanfer, 2008). In terms of faultlines, Bezrukova et al. (2009) reported a positive moderation of team identification as a primary study in this area.

However, there has been surprisingly little discussion about the role of leadership in relation to diversity, particularly because several authors have proposed leadership as a promising factor that could moderate diversity positively through higher motivation (Timmerman, 2000; van Knippenberg, De Dreu, \& Homan, 2004). To our knowledge, only three studies have targeted this specific aspect. First, Somech (2006) found that participative leadership was a moderator in the relationship between functional diversity and team reflection, which in turn favored team innovativeness. Second, Shin and Zhou (2007) found that transformational leadership moderates the relationship between educational background diversity and team creativity. Third, Kearney and Gebert (2009) found transformational leadership to be a moderator for the relationship of age, nationality, and educational diversity with the elaboration of task-relevant information, collective team identification, and via mediation also on team performance. However, none of these studies considered leadership in relation to faultlines based on several demographic characteristics of team members.

The goal of this article is to integrate two streams of diversity research, faultlines and favorable boundary conditions, in order to shed light on processes that occur as a result of increasing age diversity in combination with other demographic characteristics. Age-based faultlines, consisting of the age subgroup structure of a team in alignment with tenure and sex characteristics, are tested for their relationship to perceived productive energy of those teams. In a second step, transformational leadership is introduced as a possible moderating factor for achieving productive energy in diverse work teams. This research follows van Knippenberg et al.'s (2004) call for research on taskmotivation factors, such as leadership, in analyses of diversity issues. Thus, we test if transformational leadership is an appropriate behavior for team leaders who want to capitalize on the potential of different subgroups that are based on age and other characteristics in their team composition.

\section{The Construct of Productive Organizational Energy}

We applied the construct of teams' productive energy as the dependent variable. Productive energy, defined as the positive and intense force with which a collective works, consists of emotional, cognitive, and behavioral dimensions (Cole, Bruch, \& Vogel, 2005; Walter \& Bruch, in press). It can be characterized as an emerging intense collective state of a work group, which can be mutable and fluid and may vary frequently, even over fairly short periods of 
time (Marks, Mathieu, \& Zaccaro, 2001). Teams' productive energy, in particular, is characterized by team members' joint experience of positive affective arousal, members' shared cognitive activation in pursuit of common goals, and members' collective efforts to achieve such goals (Bruch \& Goshal, 2003; Cole et al., 2005; Walter \& Bruch, in press). Although these dimensions are conceptually and empirically distinct, they have been shown to be positively related and to conjointly reflect a team's collective energy (Cole et al., 2005; Walter \& Bruch, in press). The construct has also been shown to be empirically distinct from related measures, such as collective efficacy, collective motivation, collective autonomy, and cohesion (Cole et al., 2005) and has been argued to be an important driver of team and organizational performance (Bruch \& Goshal, 2003; Cross, Baker, \& Parker, 2003).

We hold that teams' productive energy is a suitable construct with which to capture the effects of group diversity because we assume that all three dimensions are affected by the processes that occur in teams with age-based faultlines. Similarly, the effects of leadership have been conceptualized to manifest on a cognitive, affective, and behavioral dimension (Kark \& van Dijk, 2007). We also follow the call by several authors who have suggested that multiple aspects of collective interaction should be studied simultaneously, as opposed to single variables, because they do a better job of capturing the complex reality of how groups of people together work toward shared goals (Arrow, McGrath, \& Berdahl, 2000; Hambrick, 1994; McGrath, Arrow, $\&$ Berdahl, 2000). Such complex processes can be measured only by integrated perception measures such as productive energy. In addition, this approach contributes to the emerging literature on positive organizational scholarship (Cameron \& Caza, 2004; Luthans \& Youssef, 2007).

The general research question of this article is the following: "What influences do age-based faultlines have on teams' productive energy, and are these effects moderated by transformational leadership to increase productive energy in heterogeneous teams?" By answering this question, we propose to make valuable contributions to the faultline, team diversity, leadership, and positive organizational scholarship literature.

\section{Hypotheses Development}

\section{Effect of Age-Based Faultlines on Perceived Productive Energy}

Age-based faultlines are the result of subgroup formation based on diversity in age categories that is aligned with other demographic characteristics such as tenure and sex (Lau \& Murninghan, 1998; Shaw, 2004). Age-based faultline 
strength increases if the age-based subgroups have few other aligned demographic characteristics that transcend the subgroups. Age-based faultines are weaker if members of age-based subgroups have overlapping characteristics with the members of other subgroups (Shaw, 2004).

As briefly mentioned above, the empirical findings on the effects of age diversity on team and organizational outcomes are mixed across numerous studies (Jackson et al., 2003; van Knippenberg \& Schippers, 2007). Many studies, however, report negative effects of age diversity on team outcomes (e.g., Ely, 2004; Leonard et al., 2004; Timmerman, 2000). The emerging faultline literature gets to similar results. Sawyer, Houllette, and Yeagley (2006), for example, as well as Homan, van Knippenberg, Van Kleef, and De Dreu (2007), found teams with strong faultlines to be poorer performing than those with overlapping demographic characteristics. Others (e.g., Polzer, Crisp, Jarvenpaa, \& Kim, 2006) have reported increased team conflict and distrust because of team faultlines. These results are in line with the primarily conceptual definition by Lau and Murnigham (1998), who described faultlines as inherently deleterious because they trigger harming processes such as conflict and reduced communication.

The theoretical arguments for these negative effects can be drawn from social identity theory (Tajfel \& Turner, 1986) and self-categorization theory (Turner, 1985). These theoretical approaches assume that individuals strive for positive social identity, which they receive through categorization by various demographic characteristics (e.g., sex, age, attitudes). A large part of their social identity arises from belonging to a specific social group. Consequently, members of one's own group (in-group) are favored at the expense of other groups (out-groups). Tajfel and Turner (1986) showed that the mere act of individuals' categorizing themselves as group member is sufficient to display in-group favoritism.

Aspiring social identification can be explained by a basic human need for positive self-esteem. The implication here is that self-esteem motivates social identification, and social identity satisfies the need for self-esteem (Abrams \& Hogg, 1988; Hogg, 2001). A second decisive motivation for social identity processes is to reduce subjective uncertainty (Hogg, 2000; Hogg \& Abrams, 1993; Hogg \& Mullin, 1999). The process of self-categorization reduces uncertainty because perceptions, attitudes, feelings, and behavior are now defined by an in-group model that usually has the consensual support of other group members (Hogg, 2001). If strong faultlines based on age and other demographic characteristics subsist in a work group these effects are even more likely to occur compared with the situation were only one diversity criterion leads to categorization processes. The alignment on several characteristics may increase the subjective assumption that values and scripts 
are congruent to their fellow subgroup members (Phillips, Mannix, Neale, \& Gruenfeld, 2004).

If within a work team age-based faultlines are present, negative impacts that affect all three dimensions of teams' productive energy are likely to occur. First, categorization processes in different age brackets, aligned with other demographic characteristics, as proposed by the social identity approach, can easily cause discrimination and self-segregation and finally lead to conflicts in teams (Jehn, Northcraft, \& Neale, 1999). Li and Hambrick (2005), for example, found faultlines to be related to emotional conflict in teams. Therefore, the emotional energy component of a team is likely to be lowered by stronger agebased faultlines. Second, age-based faultlines may also affect a team's behavioral potential, defined as the extent to which unit members are engaged in active, focused, and purposeful behavior to realize team objectives. The emotional conflict that can result from diversity on age, aligned with tenure and sex, may lower collective energetic behavior because team members focus more on interpersonal disagreement or other nonwork issues rather than on collective team tasks (Jehn, 1995; Lau \& Murnighan, 2005). Instead of focusing their collective behavior on common team goals, members of different age-based subgroups within the team mainly promote the diverse aims of their own subgroups, because they have a reduced motivation to contribute to a group as a whole (Wit \& Kerr, 2002) and hinder the optimal team energetic behavior. Finally, age-based faultlines might also influence the cognitive dimension of collective team energy. With mutual age stereotyping, it can be difficult to think as a collective, act productively on a problem, and mobilize the collective cognitive energy to achieve common group goals. This assumption is supported by research that found a negative association between faultline strength and team creativity (e.g., Pearsall, Ellis, \& Evans, 2008).

In sum, teams with age-based faultlines are likely to experience conflicts and less frequent communication between different age-based subgroups, which may negatively influence all three dimensions of a team's productive energy. Therefore, our first research hypothesis is as follows:

Hypothesis 1: Age-based faultlines within work teams negatively influences perceived teams' productive energy.

\section{The Moderating Effect of Transformational Leadership}

Certain leadership behavior as a solution to profit from diversity in team settings has been considered thus far only by a limited number of authors (e.g., Bass, 1998; Chrobot-Mason \& Ruderman, 2004; Kearney \& Gebert, 2009; 
Loden \& Rosener, 1991). However, to our knowledge no study has researched the relationship of team faultlines and leadership. Therefore, we argue that a transformational leader is able to create a collective social identity by providing an inspiring vision and desirable objectives for all age-based subgroups.

A transformational leader is defined as someone who can act "proactive, raise followers' awareness for transcendent collective interests and help followers to achieve extraordinary goals" (Antonakis, Avolio, \& Sivasubramaniam, 2003, p. 264). A literature review by Podsakoff, MacKenzie, and Bommer (1996) reveals that most of the numerous conceptualizations associate transformational leadership with six key behaviors. These behaviors include identifying and articulating a vision for the future, acting as an appropriate role model, fostering the acceptance of common goals, setting high performance expectations, and providing individualized support and intellectual stimulation for followers.

Through an inspirational and individually considerate leadership style (Shamir, House, \& Arthur, 1993), transformational leaders can compensate the effects of interindividual differences because of age and other characteristics through a new task-related social identity, which serves a cross-cutting feature across age-based subgroups. A transformational leader is someone who captures the will of followers by reconciling their personal goals with those of the collective team (Haslam, 2001). The new predominant social identity is that of team membership, and all team associates are thereby classified as in-group members. When all group members perceive themselves as sharing common goals and thereby possess a shared identity, processes of faultline formations and associated biases are reduced (Gaertner \& Dovidio, 2000; Gaertner, Dovidio, Anastasio, Bachman, \& Rust 1993). As a consistent effect group emotional conflicts should be less likely to occur. Team members experiencing high transformational leadership should be able to use their cognitive potentials collectively "by asking questions, seeking feedback, experimenting, reflecting on results and discussing errors and unexpected outcomes" (Edmondson, 1999, p. 353). Also acting uniformly of common team goals should be facilitated because interchange of information may increase shared member task understanding and thus alleviate group task completion (Lau \& Murnighan, 2005). Team members supervised by a transformational leader should be able to reach joint experience of emotional arousal, cognitive activation, and engaged positive behavior in pursuit of shared goals, independent of age-based faultlines.

This argumentation is in line with past research in leadership literature. According to House and Shamir (1993), transformational leadership positively influences the unit attachment of followers. Charismatic leadership is effective 
because it induces identification with the collective and keeps the collective identity salient. This leadership style endangers followers' self-efficacy and collective efficacy in pursuit of common goals (Conger \& Kanungo, 1998; Shamir et al., 1993). Yukl (2002) similarly argues that direct leadership behavior strengthens a "we-feeling" and a sense of belonging for unit members. Furthermore, Jung and Sosik (2002) found empirical support for the positive relation between transformational leadership and team cohesiveness through collective identification. Experimental studies over the years have demonstrated that assignment of a subordinated goal can decrease intergroup conflict (Tsui \& Gutek, 1999). Finally, as support for the underlying mechanism, Bezrukova et al. (2009) have shown that collective team identification moderates the effect occurring between faultines and performance.

Thus, it is very likely that in teams with high perceived transformational leadership, all three dimensions of teams' productive energy will increase, even in the case of strong age-based faultlines. The categorization based on accordance of all team members superposes all other categorizations that are based on individual attributes where the team members are dissimilar. Therefore, a transformational leader should be able to keep the destructive effects of faultlines in check while equally allowing the positive effects of diversity, such as a larger pool of informational resources, skills, and knowledge for collective performance, as proposed by the information and decision-making theories (Kilduff et al., 2000; Williams \& O’Reilly, 1998).

Thus, our second hypothesis is as follows:

Hypothesis 2: Transformational leadership moderates the relationship between age-based faultlines and perceived productive energy, such that this effect is positive when levels of perceived transformational leadership are high, but negative when levels of perceived transformational leadership are low.

\section{Method}

\section{Sample and Data Description}

Participants were employed by a multinational company that produces construction tools and applications. At the time of the survey, the company employed approximately 18,000 employees worldwide. Our sample was drawn from six different business sites in four countries: Austria, Germany, Liechtenstein, and the United Kingdom. At these six sites, all employees received an invitation from the Human Resource Department to participate in 
the study. It was possible to fill in either a web-based or a paper-based version of the questionnaire. The surveys were offered in German and English, as both languages are routinely used in the company's internal communication. Translations to German were conducted using professional translators following a double-blind, back-translation procedure (Schaffer \& Riordan, 2003).

In total, 1,400 employees were invited to respond to the current research study. Participation was voluntary, and complete anonymity was guaranteed for all participants. Therefore, we were not able to trace nonrespondents to test for response bias. Finally, 710 employees returned their surveys, producing a participation rate of $51 \%$ ( $72 \%$ web based; $28 \%$ paper based). To aggregate data on the team level, employees had to fill in their respective team numbers. The company is structured into work teams, which guarantees that the team members under investigation collaborated together. For aggregation purposes, it seemed reasonable to retain only responses from teams that yielded three or more completed surveys. Hence, teams with less than three respondents were excluded from the final data set. The final data set then consisted of 664 individuals, for a usable response rate of $47 \%$, in 72 teams. The team size varied between 3 and 26, with an average of roughly 9 members $(M=9.22 ; S D=$ 5.74). To control for a potential bias in our results caused by this relatively wide team size variation, we reran our analysis considering only teams with 12 members or less $(n=56)$, which did not change the pattern of our results.

The typical participant in the final sample was male (83\%), between 25 and 55 years $(85 \%)$, and reported an organizational tenure of more than 10 years (41\%). Respondents were primarily from lower hierarchal levels, identified as "employees without direct reports."

\section{Measures}

Age-based faultlines. To measure the age-based faultlines, we used the measure developed by Shaw (2004) because it allows faultline scores to be calculated relative to an individual attribute for categorical variables. The age-based faultline score consists of two components: internal subgroup alignment and cross-subgroup alignment for age-based groups, and the overall faultline score is computed as the product of internal subgroup alignment (IA) and the reciprocal of the cross-subgroup alignment (1-CGA; Shaw, 2004). The resulting formula is the following:

$$
\mathrm{FLS}_{\text {age }}=\mathrm{IA}_{\text {age }} \times\left(1-\mathrm{CGA}_{\text {age }}\right) .
$$


We also considered tenure and sex in the age-based faultline calculation because we wanted to account for other social categories (e.g., sex) and information-based characteristics (e.g., tenure) because both have proven to be relevant in faultline formation (Bezrukova et al., 2009). All characteristics were gauged in categorical measures. For example, employees were asked to classify themselves into one of five age categories: less than 25 years $(n=47)$, 25 to 35 years $(n=221), 36$ to 45 years $(n=238), 46$ to 55 years $(n=111)$, and more than 56 years $(n=41)$. Six respondents did not indicate their ages. This procedure was used in response to an anonymity requirement by the company that precluded us from asking for exact age. Even though age measured by a metric variable would be more desirable from methodological and theoretical points of view, using categorical measures for age is a practice widespread in organizational research (e.g., Finegold, Mohrman, \& Spreitzer, 2002; Kirkman, Tesluk, \& Rosen, 2004. Similar procedures were used for tenure: less than 1 year $(n=65), 1$ to 5 years $(n=173), 6$ to 10 years $(n=$ $141)$, and more than 10 years $(n=277)$, with eight employees not responding. There were 552 male participants and 106 female participants, with six employees not responding.

The FLS ${ }_{\text {age }}$ score can vary between 0 and 1 . A score of 0 occurs when members of one age group share no other attributes in terms of sex and tenure, but the individual members of an age group do share similar attributes (tenure and sex) with members of other groups. In this case, no subgroup internal alignment is present, whereas cross-subgroup alignment is high (Shaw, 2004). If the score is 1 , the situation is reversed, with internal alignment within the age groups but no alignment across the subgroups.

Productive energy. To gauge productive energy, we deployed the 14-item scale constructed by Cole et al. (2005) and recently applied by Walter and Bruch (in press). This measure was designed to cover the three dimensions of productive energy: Emotional (five items), cognitive (five items), and behavioral (four items). The construct validity of productive energy was tested by Cole et al. (2005) in three studies, resulting in acceptable psychometric properties. Cole et al. (2005) further successfully tested the cross-cultural and cross-language measurement equivalence across five national cultures. In line with Cole et al. (2005), we used a 5-point Likert-type response scale that ranged from 1 (strongly disagree) to 5 (strongly agree), for the cognitive items (e.g., "At the present time people in my work group are mentally alert") and behavioral (e.g., "People in my work group often work extremely long hours without complaining"). The emotional items (e.g., "People in my work group feel inspired in their work") applied a 5-point frequency scale, ranging from 
1 (never) to 5 (frequently, if not always). Because the construct is relatively new we carried out a confirmatory factor analysis to check for a second-order three-dimensional structure. Results revealed a good fit of the model to our data $\left(\chi^{2}=157.469 ; d f=74\right.$; confirmatory fit index $=.968$; Tucker-Lewis index $=.955$; root mean square error of approximation $=.041)$. Based on these results, we averaged all item responses to form an overall productive energy score (Cole et al., 2005; Walter \& Bruch, in press).

As we are interested in productive energy at the team level, we aggregated the individual scores for every team. Following the recommendation by Bliese (2000), we calculated three different aggregation statistics $\left(r_{\mathrm{wg}}, \mathrm{ICC}_{1}, \mathrm{ICC}_{2}\right)$. $r_{\text {wg }}$ assesses whether employee member ratings within a given unit are interchangeable. $\mathrm{ICC}_{1}$ displays the existence of group effect on the variable of interest, whereas $\mathrm{ICC}_{2}$ estimates the reliability of the group means (Bliese, 2000). Although there are no absolute standards for these indices, $\mathrm{ICC}_{1}$ values based on significant $F$ statistics from a one-way analysis of variance, $\mathrm{ICC}_{2}$ values of more than .50 , and median $r_{\mathrm{wg}}$ of more than .70 are usually considered as sufficient (Bliese, 2000; Kenny \& La Voie, 1985; Klein \& Kozlowski, 2000). All three statistics showed sufficient results $\left(\mathrm{ICC}_{1}=.14\right.$; $F=2.46, p<.001 ; \mathrm{ICC}_{2}=.60 ;$ median $r_{\mathrm{wg}}=.89$ ), indicating that aggregation to the team level is a reasonable procedure. The internal consistency of productive energy on the team level was $\alpha=.89$.

Transformational leadership. We used ratings from Bass and Avolio's (2000) multifactor leadership questionnaire (MLQ 5x-short) to assess transformational leadership (TFL). The MLQ is widely used in empirical leadership research and has shown to provide acceptable psychometric properties (Antonakis et al., 2003). Through 20 items, the questionnaire assesses the five dimensions of transformational leadership: idealized influence (attributed and behavioral), inspirational motivation, intellectual stimulation, and individualized consideration. Followers were asked to judge how often their leader exhibited such leadership behavior on a 5-point Likert-type scale, ranging from 1 (not at all) to 5 (frequently, if not always). As commonly practiced in prior research (e.g., Avolio, Zhu, Koh, \& Bhatia, 2004; Bommer, Rich, \& Rubin, 2005), we averaged the item responses to generate a general transformational leadership score. Additionally, we aggregated individual scores to the team level, in order to reach a unique transformational leadership score for each leader of a specific team. To establish appropriateness of this aggregation procedure, we computed the same aggregation statistics as for productive energy. All three statistics showed sufficient results $\left(\mathrm{ICC}_{1}=.11 ; F=2.07, p<.001 ; \mathrm{ICC}_{2}=\right.$ .52 ; median $r_{\text {wg }}=.83$ ). The internal consistency estimate was $\alpha=.88$. 
Controls. There are several other variables that might also influence productive energy in work teams. First of all, we believe that team size should have a decisive impact on team performance as found in previous studies (Mullen et al., 1991; Wegge et al., 2008). Previous research has demonstrated that team size affects team processes, such as cohesiveness and communication (e.g., Ancona \& Caldwell, 1992; Bantel \& Jackson, 1989). Second, we also accounted for national and cultural differences as possible sources of influence. Demographic factors, such as age, are important in any society and societal setting but may have different meanings (Tsui \& Gutek, 1999). Therefore, we controlled for different cultural backgrounds in our sample by discriminating between teams from Lichtenstein, Austria, and Germany, as one common cultural area, and Great Britain, by dummy coding of an additional variable. Such a classification is in line with Gupta, Hanges, and Dorfman (2002), who found Austria, Germany, and Liechtenstein belonging to a Germanic cultural cluster and United Kingdom belonging to an Anglo-Saxon cultural sphere.

\section{Data Analysis}

We tested Hypotheses 1 and 2 by applying hierarchical regression analyses at the team level (Aiken \& West, 1991; Cohen \& Cohen, 1983). Primarily, all controls were entered simultaneously in the regression. In a second step, to address Hypothesis 1, we added the age-based faultline measure as well as the TFL construct. Third, we inserted the cross-product of transformational leadership and age-based faultlines to the equation to test for the moderation hypothesis. Following the advice of Aiken and West (1991), the two variables of interest were grand-mean centered to reduce the risk of multicollinearity bias. Finally, interaction effects were displayed graphically to ease their interpretation. We also did some further statistical analysis to control for impotent control variables.

\section{Results}

\section{Descriptive Statistics}

Table 1 presents mean, standard deviation, and bivariate correlations for all investigated variables, including age, tenure, and sex as the components of the age-based faultlines. As expected, age-based faultlines were negatively related on a significant level to productive organizational energy $(r=-.29$; $p<.03$ ). Some other variables showed significant bivariate relationships; 
Table I. Descriptive Statistics

\begin{tabular}{lcccccccccc}
\hline Variables & $M$ & $S D$ & 1 & 2 & 3 & 4 & 5 & 6 & 7 & 8 \\
\hline $\begin{array}{l}\text { I. Productive } \\
\quad \text { Energy }\end{array}$ & 3.77 & 0.27 & $(.89)$ & & & & & & \\
$\begin{array}{l}\text { 2. Age-Based } \\
\quad \text { Faultline }\end{array}$ & 0.57 & 0.16 & $-.29 *$ & - & & & & & \\
3. Age & 2.9 & 0.57 & .10 & $.23^{*}$ & - & & & & \\
4. Tenure & 2.8 & 0.44 & .12 & $.31^{*}$ & $.59^{* *}$ & - & & & \\
5. Sex & 1.2 & 0.21 & -.13 & .03 & .05 & -.02 & - & & \\
6. Transformational & 3.82 & 0.36 & $.57^{* *}-.07$ & .04 & -.02 & -.07 & $(.88)$ & \\
$\quad$ Leadership & & & & & & & & & & \\
7. Team Size & 9.22 & 5.74 & .17 & $.53^{* *}$ & $.23^{\dagger}$ & .16 & .03 & -.06 & - & - \\
8. Country & 0.58 & 0.50 & -.09 & -.18 & .13 & .15 & -.14 & -.05 & $-.24^{*}$ & - \\
\hline
\end{tabular}

Note: $N=72$ work teams. Internal consistency reliabilities shown in brackets.

$*^{*} p<.001 .{ }^{*} p<.05 .{ }^{\dagger} p<.10$, two-tailed.

however, none appeared in such way that could lead to serious multicollinearity problems in our regression analysis.

\section{Hypotheses Testing}

Table 2 lists all hierarchical regression results sufficient to address the hypotheses under research. Step 1 shows the results solely for the two control variables - team size and country. None of these factors illustrated a significant association to the dependent variable. Step 2 illustrates the results for the impact of age diversity and TFL together with all controls. The hypothesized negative relationship of age-based faultlines on teams' productive energy that we had discovered previously in the descriptive analysis is still present, however only at a marginal significant level $(p<.08)$. Together with TFL age-based faultlines contributed additionally $34 \%$ to the explained variance. Thus, Hypothesis 1 is partly supported.

In Step 3, we finally entered the interaction term of transformational leadership and age-based faultlines in the regression equation. The result showed a significant and positive impact of the interaction effect $(\beta=.18 ; p<.03)$. The interaction term contributed $3 \%$ additionally to the variance explained in teams' productive energy, after considering transformational leadership, agebased faultlines, and all controls. Following the advice by Lubinski and Humphreys (1990), we tested for a possible curvilinear relationship by 
Table 2. Moderated Hierarchical Regression Analysis

\begin{tabular}{lccc}
\hline Variables Entered & Step I & Step 2 & Step 3 \\
\hline Team Size & -.17 & -.06 & -.06 \\
Country & .02 & .03 & .04 \\
Age-Based Faultlines & & $-.17^{\dagger}$ & $-.18^{\dagger}$ \\
Transformational & & $.56^{* *}$ & $.58^{* *}$ \\
$\quad$ Leadership & & & $.18^{*}$ \\
Age-Based Faultlines & & & \\
$\quad *$ Transformational & & $.34^{* *}$ & $.03^{*}$ \\
$\quad$ Leadership & & $.37^{* *}(.33)$ & $.40^{*}(.35)$ \\
$\mathrm{R}^{2}$ & $.03(.00)$ & & \\
$\mathrm{R}^{2}$ (adjusted $\left.\mathrm{R}^{2}\right)$ & &
\end{tabular}

Note: $N=72$ work teams. Standardized regression weights are shown.

${ }^{* *} p<.001 .{ }^{*} p<.05 .{ }^{\dagger} p<.10$, one-tailed.

entering the quadratic predictor variables in the equation. Neither turned out to be significant, indicating no suspicion of a nonlinear relationship. We also checked once again whether multicollonearity was a problem in our analysis by inspecting the variance inflation factor. With maximum values of 1.44 , they indicated no suspicion for multicollinearity in our analysis. To better interpret the form of interaction between transformational leadership and age-based faultlines, we plotted it graphically in Figure 1 (Aiken \& West, 1991). To form the graph, the regressions lines of age-based faultlines on perceived productive energy were plotted under the condition of low and high perceived transformational leadership within teams (using one standard deviation below and above the mean as a reference point). As one can see, in the case of high transformational leadership, the relationship between agebased faultlines and perceived productive energy turns slightly positive, whereas for low transformational leadership, we see a strong negative relationship. In other words, transformational leadership was found as an important boundary condition to achieve productive energy in teams with strong faultlines. Therefore, Hypothesis 2 was supported.

Following the advice from Becker (2005), we reran all regression steps without including control variables to account for possible biased results because of the presence of impotent control variables. These analyses did not produce any deviating results, a finding that further strengthens the robustness of our results. 


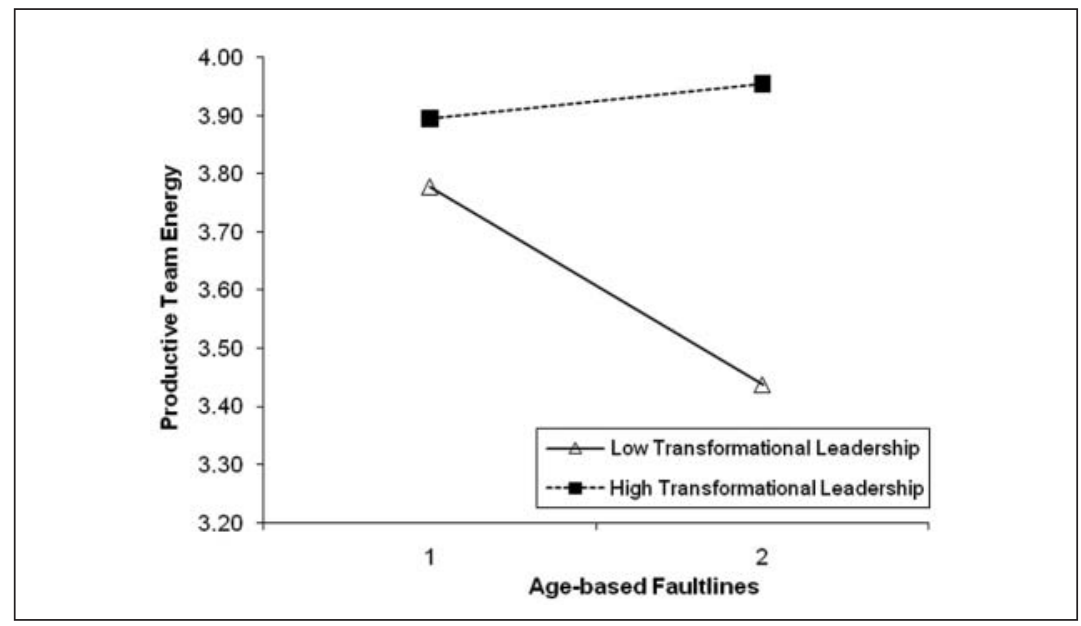

Figure I. Transformational leadership as a moderator of the relationship between age-based faultlines and productive team energy

\section{Discussion and Conclusion}

The purpose of our study was first to examine the impact of age-based faultlines on productive energy at the team level and second to test whether transformational leadership can moderate this relationship. For the first research question, no final answer can be drawn from this research. Age-based faultlines are only marginally significant as a negative impact factor. Thus, our study joins prior research that found negative impacts of faultline strength on group performance and behavioral integration (Homan et al., 2007; Li \& Hambrick, 2005; Polzer et al., 2006; Sawyer et al., 2006). Our study offers first evidence that this negative impact of faultlines might also be true for the relationship of age-based faultlines and perceived productive energy. Whether this effect on a .08 error margin is reliable and stable must be investigated in future replication of our results.

Concerning the second hypothesis, our study suggests that transformational leadership moderates the relationship between age-based faultlines and productive energy of teams. The interaction between age-based faultlines and transformational leadership makes a prominent contribution to the variance of teams' productive energy. Teams with faultines consisting of the alignment of age subgroups with sex and tenure that possess a high level of perceived 
transformational leadership are significantly more capable of collectively energizing their multidimensional energy potentials than are teams low on this variable. These results present a valuable contribution to the faultline, diversity, as well as leadership literature. Transformational leadership seems to be an important moderating factor to use to explain the possible positive effects of age-based faultlines. Thus, we were able to show that transformational leadership is not only a positive moderator for single diversity dimension, as shown by Kearney and Gebert (2009), but is also a positive context factor for age-based faultlines, considering tenure and sex of the team members. By creating an integrative social identity for all team members based on workrelated issues, a transformational leader seems capable of overcoming the negative dynamics of age-based faultlines, such as emotional conflicts because of different social identities.

With the right leadership behavior the positive dynamics of diversity, which so far were mainly reported in studies under experimental settings (e.g., Cox, Lobel, \& McLeod, 1991; Priem, Rasheed, \& Kotulic, 1995), seem to be reachable even in a real business environment. Therefore, we conclude that transformational leadership may enable productivity and performance beyond expectation (Bass, 1985) not only for individuals but also for teams with strong age-based faultlines.

\section{Practical Implications}

Our study has numerous practical implications. Because of ongoing demographic change, nearly all companies in the Western world will be confronted sooner or later with more age heterogeneous staff and work teams. When this age diversity is accompanied by aligned diversity on other characteristics (e.g., tenure, age) faultlines may emerge, with negative consequences on team processes. Thus, knowledge for how to lead and manage such teams productively should be a crucial factor for success in the near future. Emerging conflicts because of mutual stereotyping within teams are a threat to energy and productivity in teams. Our research suggests that transformational leadership behavior is an auspicious strategy to use to profit from age-based faultlines. In contrast to the previously identified moderators of the faultline and diversity-outcome relationships (e.g., team size, team identification, or task characteristics), transformational leadership is a directly controllable factor, because previous research has shown transformational leadership to be a skill that can be developed (e.g., Barling, Weber, \& Kelloway, 1996) and could hence be a key solution to reach productive energy and high performance of work teams. 
These results entail important implications for leadership training and development in companies. Companies should, for example, sensitive their leaders for potential age diversity impacts on team processes and performance, for example, by holding special age awareness seminars as proposed by Elliot (1995) or Armstrong-Stassen and Templer (2005). Leaders should be aware of potential conflicts due to mutual age stereotypes, which might increase if age diversity is aligned with tenure and sex of the team members, and be ready to react if these endanger the productive energy within their groups. This is best reached if leaders are able to create a common social identity through their transformational leadership behavior by, for example, creating an ambitious vision that appeals to all group members (e.g., "our team should be the leading source for new ideas in our company"). With transformational leadership, this vision is then communicated and transferred through charismatic behavior, intellectual stimulation, and individual consideration for all team members. This is best reached if leaders are able to create a common social identity through their transformational leadership behavior. That can be reached, for example, by creating an ambitious vision that seems appealing for all group members (e.g., "our team should become the leading source for new ideas in our company"). This vision needs than to be communicated and transferred through charismatic behavior, intellectual stimulation, and individual consideration of all team members.

Companies with a high age heterogeneous profile should put special emphasize on transformational leadership training to enable their managers to reach and maintain a high level of productive energy within their companies. Prior research has shown the positive relation of productive organizational energy to outcome and performance variables, such as collective goal commitment, affective commitment, and job satisfaction climate (Bruch, Vogel, \& Cole, 2006) as well as for the overall company performance (Bruch, Cole, Vogel, \& Menges, 2007). Therefore, keeping productive energy at a high level should facilitate the increased performance of the entire company.

\section{Limitations and Future Research Directions}

As in nearly every kind of empirical research, there are several limitations that restrict the interpretation and generalization of any findings. First of all, the data for this study were collected only at one point in time, and employees and teams included in the sample were not randomly assigned to the research. Therefore, no final conclusion about causality can be drawn. Future studies might overcome these weaknesses by applying longitudinal and quasi-experimental research designs (Shadish, Cook, \& Campbell, 2002). 
Additionally, the generalizability might be limited because our data were taken from just one company. Future research might enhance the validity of the findings by including other companies.

Second, as all data were taken from one single data source, a self-report employee survey, our results might be biased by common method variance (Podsakoff, MacKenzie, Lee, \& Podsakoff, 2003). However, a bias is relatively unlikely for both our hypotheses. For the first hypothesis the independent variable, age-based faultlines, is calculated out of the rather objective assessment of the demographics by the respondents and thus not based on subjective personal assessments as the outcome variable productive energy. Concerning the second hypothesis, testing for interaction effects, common method problems are even more implausible. As Evans (1985) demonstrated through a Monte Carlo study, it is improbable to draw an incorrect inference caused by artifactual common method inference in the instance of testing for interaction terms. Therefore, common method variance should only be of minor concern for our results.

Third, the categorical measurement of age in our research, triggered by anonymity requirements, might be problematic. Compared with a continuous measurement of age, we definitely lose information when assessing the employees only in five age categories. Furthermore, a continuous age variable would also allow us to use more precise indices, such as the coefficient of variation (Allison, 1978; Harrison \& Klein, 2007). Thus, future studies should aim at a more precise measurement of age.

Finally, we are also aware of the problem raised by Allen, Stanley, Williams, and Ross (2007) that nonresponse of group members might distort the group's diversity scores and bias our findings. Unfortunately, we did not have access to archival data sources that may circumvent these problems. As a solution, we reran our regression analyses with only those teams for which we had a within team response rate of $>70 \%(n=19)$ and of $>50 \%(n=39)$, which did not change the overall pattern of our results. Therefore, we conclude that nonresponse of demographics characteristics did not substantially bias our results. Nevertheless, future studies should aim at replicating our results with data sets providing complete demographic information from employees.

Beyond these limitations, our study suggests several interesting directions for future research. First, given that diversity is clearly a multilevel construct because it describes a unit in terms of the collective composition of its members, a multilevel approach, as proposed by several authors (e.g., Harrison \& Klein, 2007; Jackson et al., 2003; Tsui \& Gutek, 1999), seems appropriate for studying the effects of age-based faultlines. Future studies might, for example, also consider the implications of faultlines for the motivation and performance 
of each individual in a specific group rather than solely considering teamlevel outcomes.

Second, future research could expand the present study by considering dependent variables other than productive energy. We decided to focus on productive energy because this variable covers the emotional, cognitive, and behavioral potential of a work team (Cole et al., 2005; Walter \& Bruch, in press). In the reasoning of Mathieu, Maynard, Rapp, and Gilson (2008), productive energy is an emergent state that should function as a mediator between group input (e.g., faultlines) and outcomes (e.g., performance). Following this logic, future studies should integrate our results in a moderatedmediation model with team performance measures as outcome variables. Future research may also attempt to measure productive energy in more objective ways than by subjective assessment of the team members. For example, the cognitive part of productive energy may be gauged in terms of team creativity (e.g., number of new ideas generated), whereas the behavioral component of productive energy may be operationalized by the number of voluntary extra hours worked or the pace of work accomplishment. A way to objectively measure the emotional component may be to count the number of positive emotional statements on collective group goals in a team's communication.

Third, future research may also consider faultline operationalizations other than age-based faultlines, considering tenure and sex. Upcoming studies may, for example, test whether our results may be replicable with faultlines based on other combinations of demographic properties such as deep-level diversity characteristics (e.g., personalities, values, and attitudes; Harrison, Price, \& Bell, 1998). Another possibility may be to test the moderation of transformational leadership separately for information-based and social category-based faultlines (Bezrukova et al. 2009).

Finally, to understand the complex process that occurs between age-based faultlines, team processes, and team outcomes, far more complex models need to be developed to capture the phenomena fully. Transformational leadership is only one of several potential moderators in the described process. Roberge and Van Dick (2007), for example, recently theoretically proposed collective identity salience and psychology safety climate as important conditions under which diversity may increase group outcomes. Directly including the assumed mechanism in empirical research, as in our study social categorization processes, may also help more fully understand the faultline-outcome linkage (van Knippenberg \& Schippers, 2007). Additionally, we hope that our research may encourage other scholars from both leadership and diversity backgrounds 
to research the important role that leadership may play in utilizing the benefits of diversity in today's organizations. Thus, our study is just a starting point for the future research that will undoubtedly appear.

\section{Declaration of Conflicting Interests}

The author(s) declared no conflicts of interest with respect to the authorship and/or publication of this.

\section{Funding}

The author(s) received no financial support for the research and/or authorship of this article.

\section{References}

Abrams, D., \& Hogg, M. A. (1988). Comments on the motivational status of selfesteem in social identity and intergroup discrimination. European Journal of Social Psychology, 18, 317-334.

Aiken, L. S., \& West, G. (1991). Multiple regressions: Testing and interpreting interactions. Thousand Oakes, CA: Sage.

Allen, N. J., Stanley, D. J., Williams, H. M., \& Ross, S. J. (2007). Assessing the impact of nonresponse on work group diversity effects. Organizational Research Methods, 10, 262-286.

Allison, P. D. (1978). Measures of Inequality. American Sociological Review, 43, 865-880.

Ancona, D. G., \& Caldwell, D. F. (1992). Demography and design: Predictors of new product team performance. Organization Science, 3, 321-341.

Antonakis, J., Avolio, B. J., \& Sivasubramaniam, N. (2003). Context and leadership: An examination of the nine-factor full-range leadership theory using the multifactor leadership questionnaire. Leadership Quarterly, 14, 261-295.

Armstrong-Stassen, M., \& Templer, A. (2005). Adapting training for older employees. The Canadian response to an aging workforce. Journal of Management Development, 24, 57-67.

Arrow, H., McGrath, J. E., \& Berdahl, J. L. (2000). Small groups as complex systems: Formation, coordination, development, and adaptation. Thousand Oaks, CA: Sage.

Avolio, B. J., Zhu, W. C., Koh, W., \& Bhatia, P. (2004). Transformational leadership and organizational commitment: Mediating role of psychological empowerment and moderating role of structural distance. Journal of Organizational Behavior, 25, 951-968. 
Bantel, K. A., \& Jackson, S. E. (1989). Top management and innovations in banking: Does the composition of the top team make a difference. Strategic Management Journal, 10, 107-124.

Barling, J., Weber, T., \& Kelloway, E. K. (1996). Effects of transformational leadership training on attitudinal and financial outcomes: A field experiment. Journal of Applied Psychology, 81, 827-832.

Bass, B. M. (1985). Leadership and performance beyond expectations. New York, NY: Free Press.

Bass, B. M. (1998). Transformational leadership: Industries, military, and educational impact. Mahwah, NJ: Erlbaum.

Bass, B. M., \& Avolio, B. J. (2000). Manual for the multifactor leadership questionnaire. Reedwood City, CA: Mindgarden.

Becker, T. E. (2005). Potential problems in the statistical control of variables in organizational research: A qualitative analysis with recommendations. Organizational Research Methods, 8, 274-289.

Bezrukova, K., Jehn, K. A., Zanutto, E. L., \& Thatcher, S. M. B. (2009). Do workgroup faultlines help or hurt? A moderated model of faultlines, team identification, and group performance. Organization Science, 20, 35-50.

Bliese, P. D. (2000). Within group agreement, non-independence, and reliability. In K. J. Klein \& S. W. Kozlowski (Eds.), Multilevel theory, research, and methods in organizations (pp. 349-381). San Francisco, CA: Jossey-Bass.

Bommer, W. H., Rich, G. A., \& Rubin, R. S. (2005). Changing attitudes about change: Longitudinal effects of transformational leader behavior on employee cynicism about organizational change. Journal of Organizational Behavior, 26, 733-753.

Bruch, H., Cole, M. S., Vogel, B., \& Menges, J. (2007). Linking productive organizational energy to firm performance and individuals'satisfaction. Paper presented at the Academy of Management Conference, Philadelphia, PA.

Bruch, H., \& Goshal, S. (2003). Unleashing organizational energy. MIT Sloan Management Review, 45, 45-51.

Bruch, H., Vogel, B., \& Cole, M. S. (2006). Productive organizational energy: A collective model and empirical testing. Paper presented at the Academy of Management Conference, Philadelphia, PA.

Bunderson, J. S., \& Sutcliffe, K. M. (2002). Comparing alternative conceptualizations of functional diversity in management teams: Process and performance effects. Academy of Management Journal, 45, 875-893.

Cameron, K. S., \& Caza, A. (2004). Introduction: Contributions to the discipline of positive organizational scholarship. American Behavioral Scientist, 47, 731-739.

Chrobot-Mason, D., \& Ruderman, D. (2004). Leadership in a diverse workplace. In M. S. Stockdale \& F. J. Crosby (Eds.), The psychology and management of workplace diversity (pp. 100-122). London, England: Blackwell. 
Cohen, J., \& Cohen, P. (1983). Applied multiple regression. Correlation analysis for the behavioral science. Hillsdale, NJ: Lawrence Erlbaum.

Cole, M. S., Bruch, H., \& Vogel, B. (2005). Development and validation of a measure of organizational energy. Paper presented at the proceedings of the 64th Annual Meeting of the Academy of Management, Honolulu, HI.

Conger, J. A., \& Kanungo, R. N. (1998). Charismatic leadership in organizations. Thousand Oaks, CA: Sage.

Cox, T. H., Lobel, S. A., \& McLeod, P. L. (1991). Effects of ethnic-group culturaldifferences on cooperative and competitive behavior on a group task. Academy of Management Journal, 34, 827-847.

Cross, R., Baker, W., \& Parker, A. (2003). What creates energy in organizations. MIT Sloan Management Review, 44, 51-56.

Dychtwald, K., Erickson, T., \& Morison, B. (2004). It's time to retire retirement. Harvard Business Review, 82, 48-57.

Edmondson, A. (1999). Psychological safety and learning behavior in work teams. Administrative Science Quarterly, 44, 350-383.

Elliott, R. H. (1995). Human resource management's role in the future aging of the workforce. Review of Public Personnel Administration, 15, 5-17.

Ely, R. J. (2004). A field study of group diversity, participation in diversity education programs, and performance. Journal of Organizational Behavior, 25, 755-780.

European Commission. (2006). Ageing and employment: Identification of good practice to increase job opportunities and maintain older workers in employment. Brussels, Belgium: Ageing at Work.

Evans, M. G. (1985). A Monte-Carlo study of the effects of correlated method variance in moderated multiple-regression analysis. Organizational Behavior and Human Decision Processes, 36, 305-323.

Finegold, D., Mohrman, S., \& Spreitzer, G. M. (2002). Age effects on the predictors of technical workers' commitment and willingness to turnover. Journal of Organizational Behavior, 23, 655-674.

Gaertner, S. L., \& Dovidio, J. F. (2000). Reducing intergroup bias: The common ingroup identity model. Philadelphia, PA: Psychology Press.

Gaertner, S. L., Dovidio, J. F., Anastasio, P. A., Bachman, B. A., \& Rust, M. C. (1993). The common ingroup identity model: Recategorization and the reduction of intergroup bias. European Review of Social Psychology, 4, 1-26.

Gupta, V., Hanges, P. J., \& Dorfman, P. (2002). Cultural clusters: Methodology and findings. Journal of World Business, 37, 11-15.

Hambrick, D. C. (1994). Top management groups: A conceptual integration and reconsideration of the "Team" label. Research in Organizational Behavior, 16, 171-171. 
Harrison, D. A., \& Klein, K. J. (2007). What's the difference? Diversity constructs as separation, variety, or disparity in organizations. Academy of Management Review, 32, 1199-1228.

Harrison, D. A., Price, K. H., \& Bell, P. B. (1998). Beyond relational demography: Time and the effects of surface- and deep-level diversity on work group cohesion. Academy of Management Journal, 41, 96-107.

Haslam, A. S. (2001). Psychology in organizations. The social identity approach. Thousand Oaks, CA: Sage.

Hogg, M. A. (1993). Towards a single-process uncertainty reduction model of social motivation in groups. In D. Abrams (Ed.), Group motivation: Social psychology perspective (pp. 173-190). London, England: Harvester-Wheatsheaf.

Hogg, M. A. (2000). Subjective uncertainty reduction through self-categorization: A motivational theory of social identity processes. European Review of Social Psychology, 11, 223-255.

Hogg, M. A. (2001). Social categorization, depersonalization, and group behavior. In M. A. Hogg \& R. S. Tindale (Eds.), Blackwell handbook of social psychology: Group processes (pp. 56-85). Oxford, England: Blackwell.

Hogg, M. A., \& Mullin, B. A. (1999). Joining groups to reduce uncertainty: Subjective uncertainty reduction and group identification. In D. Abrams \& M. A. Hogg (Eds.), Social identity and social cognition (pp. 249-279). Oxford, England: Blackwell.

Homan, A. C., van Knippenberg, D., Van Kleef, G. A., \& De Dreu, C. K. W. (2007). Bridging faultlines by valuing diversity: Diversity beliefs, information elaboration, and performance in diverse work groups. Journal of Applied Psychology, 92, 1189-1199.

House, R. J., \& Shamir, B. (1993). Towards the integration of transformational, charismatic, and visionary theories. In M. M. Chemers \& R. Ayman (Eds.), Leadership theory and research (pp. 577-594). San Diego, CA: Academic Press.

Jackson, S. E., Joshi, A., \& Erhardt, N. L. (2003). Recent research on team and organizational diversity: SWOT analysis and implications. Journal of Management, 29, 801-830.

Jehn, K. A. (1995). A multimethod examination of the benefits and detriments of intragroup conflict. Administrative Science Quarterly, 40, 256-282.

Jehn, K. A., Northcraft, G. B., \& Neale, M. A. (1999). Why differences make a difference: A field study of diversity, conflict, and performance in workgroups. Administrative Science Quarterly, 44, 741-763.

Jung, D. I., \& Sosik, J. J. (2002). Transformational leadership in work groups-The role of empowerment, cohesiveness, and collective-efficacy on perceived group performance. Small Group Research, 33, 313-336. 
Kark, R., \& van Dijk, D. (2007). Motivation to lead, motivation to follow: The role of the self-regulatory focus in leadership processes. Academy of Management Review, 32, 500-528.

Kearney, E., \& Gebert, D. (2009). Managing diversity and enhancing team outcomes: The promise of transformational leadership. Journal of Applied Psychology, 94, 77-98.

Kenny, D. A., \& La Voie, L. (1985). Separating individual and group effects. Journal of Personality and Social Psychology, 48, 339-348.

Kilduff, M., Angelmar, R., \& Mehra, A. (2000). Top management-team diversity and firm performance: Examining the role of cognitions. Organization Science, 11, 21-34.

Kirkman, B. L., Rosen, B., Tesluk, P. E., \& Gibson, C. B. (2004). The impact of team empowerment on virtual team performance: The moderating role of face-to-face interaction. Academy of Management Journal, 47, 175-192.

Kirkman, B. L., Tesluk, P. E., \& Rosen, B. (2004). The impact of demographic heterogeneity and team leader-team member demographic fit on team empowerment and effectiveness. Group \& Organization Management, 29, 334-368.

Klein, E. B., \& Kozlowski, S. W. (2000). Multilevel theory, research, and methods in organizations: Foundations, extensions, and new directions. San Francisco, CA: Jossey-Bass.

Leonard, J. S., Levine, D. I., \& Joshi, A. (2004). Do birds of a feather shop together? The effects on performance of employees' similarity with one another and with customers. Journal of Organizational Behavior, 25, 731-754.

Lau, D. C., \& Murnighan, J. K. (1998). Demographic diversity and faultlines: The compositional dynamics of organizational groups. Academy of Management Review, 23, 325-340.

Lau, D. C., \& Murnighan, J. K. (2005). Interactions within groups and subgroups: The effects of demographic faultlines. Academy of Management Journal, 48, 645-659.

Lawrence, B. S. (1997). The black box of organizational demography. Organization Science, 8, 1-22.

Li, J. T., \& Hambrick, D. C. (2005). Factional groups: A new vantage on demographic faultlines, conflict, and disintegration in work teams. Academy of Management Journal, 48, 794-813.

Loden, M., \& Rosener, J. B. (1991). Workforce America! Managing employee diversity as a vital resource. Homewood, IL: Business on Irwin.

Lubinski, D., \& Humphreys, L. G. 1990. Assessing spurious moderators effects illustrated substantively with the hypothesized (synergistic) relation between spatial and mathematical ability. Psychological Bulletin, 107, 385-393.

Luthans, F., \& Youssef, C. M. (2007). Emerging positive organizational behavior. Journal of Management, 33, 321-349. 
Marks, M. A., Mathieu, J. E., \& Zaccaro, S. J. (2001). A temporally based framework and taxonomy of team processes. Academy of Management Review, 26, 356-376.

Mathieu, J., Maynard, M. T., Rapp, T., \& Gilson, L. (2008). Team effectiveness 19972007: A review of recent advancements and a glimpse into the future. Journal of Management, 34, 410-476.

McGrath, J. E., Arrow, H., \& Berdahl, J. L. (2000). The study of groups: Past, present, and future. Personality and Social Psychology Review, 4, 95-105.

Mullen, B. (1991). Group composition, salience, and cognitive representations: The phenomenology of being in a group. Journal of Experimental Social Psychology, 27, 297-323.

Mullen, B., Copper, C., Cox, P., Fraser, C., Hu, L. T., Meisler, A., . . Symons, C. (1991). Boundaries around group-interaction: A meta-analytic integration of the effects of group-size. Journal of Social Psychology, 131, 271-283.

Pearsall, M. J., Ellis, A. P. J., \& Evans, J. M. (2008). Unlocking the effects of gender faultlines on team creativity: Is activation the key? Journal of Applied Psychology, 93, 225-234.

Phillips, K. W., Mannix, E. A., Neale, M. A., \& Gruenfeld, D. H. (2004). Diverse groups and information sharing: The effects of congruent ties. Journal of Experimental Social Psychology, 40, 497-510.

Polzer, J. T., Crisp, C. B., Jarvenpaa, S. L., \& Kim, J. W. (2006). Extending the faultline model to geographically dispersed teams: How colocated subgroups can impair group functioning. Academy of Management Journal, 49, 679-692.

Podsakoff, P. M., MacKenzie, S. B., \& Bommer, W. H. (1996). Transformational leader behaviors and substitutes for leadership as determinants of employee satisfaction, commitment, trust, and organizational citizenship behaviors. Journal of Management, 22, 259-298.

Podsakoff, P. M., MacKenzie, S. B., Lee, J. Y., \& Podsakoff, N. P. (2003). Common method biases in behavioral research: A critical review of the literature and recommended remedies. Journal of Applied Psychology, 88, 879-903.

Priem, R. L., Rasheed, A. M. A., \& Kotulic, A. G. (1995). Rationality in strategic decision-processes, environmental dynamism and firm performance. Journal of Management, 21, 913-929.

Roberge, M. E., \& Van Dick, R. (2007). Managing workplace diversity: When and how does diversity increase group performance? Paper presented at the Academy of Management Conference, Philadelphia, PA.

Sawyer, J. E., Houlette, M. A., \& Yeagley, E. L. (2006). Decision performance and diversity structure: Comparing faultlines in convergent, crosscut, and racially homogeneous groups. Organizational Behavior and Human Decision Processes, 99, 1-15. 
Schaffer, B. S., \& Riordan, C. M. (2003). A review of cross-cultural methodologies for organizational research: A best-practices approach. Organizational Research Methods, 6, 169-215.

Shadish, W. R., Cook, T. D., \& Campbell, D. T. (2002). Experimental and quasiexperimental designs for generalized causal inference. Boston, MA: Houghton Mifflin.

Shamir, B., House, R. J., \& Arthur, M. B. (1993). The motivational effects of charismatic leadership: A self-concept based theory. Organization Science, 4, 577-594.

Shaw, J. B. (2004). The development and analysis of a measure of group faultlines. Organizational Research Methods, 7, 66-114.

Shin, S. J., \& Zhou, J. (2007). When is educational specialization heterogeneity related to creativity in research and development teams? Transformational leadership as a moderator. Journal of Applied Psychology, 92, 1709-1721.

Simons, T., Pelled, L. H., \& Smith, K. A. (1999). Making use of difference: Diversity, debate, and decision comprehensiveness in top management teams. Academy of Management Journal, 42, 662-673.

Somech, A. (2006). The effects of leadership style and team process on performance and innovation in functionally heterogeneous teams. Journal of Management, 32, 132-157.

Tajfel, H., \& Turner, J. C. (1986). The social identity theory of intergroup behaviour. In S. Worchel \& W. G. Austin (Eds.), Psychology of intergroup relation (pp. 7-24). Chicago, IL: Nelson-Hall.

Tempest, S., Barnatt, C., \& Coupland, C. (2002). Grey advantage: New strategies for the old. Long Range Planning, 35, 475-492.

Thatcher, S. M. B., Jehn, K. A., \& Zanutto, E. (2003). Cracks in diversity research: The effects of diversity faultlines on conflict and performance. Group Decision and Negotiation, 12, 217-241.

Timmerman, T. A. (2000). Racial diversity, age diversity, and team performance. Small Group Research, 31, 592-606.

Tsui, A. S., \& Gutek, B. A. (1999). Demographic differences in organizations. Current research and future directions. Lanham, MD: Lexington.

Turner, J. C. (1985). Social categorization and the self-concept: A social cognitive theory of group behavior. In E. J. Lawler (Ed.), Advances in group processes: Theory and research (pp. 77-122). Greenwhich: JAI Press.

United Nations. (2005). Population challenges and development goals. New York, NY: Author.

U.S. Bureau of Labor Statistics. (2008). Older workers. Retrieved from http://www .bls.gov/spotlight/2008/older_workers/ 
Van Knippenberg, D., De Dreu, C. K. W., \& Homan, A. C. (2004). Work group diversity and group performance: An integrative model and research agenda. Journal of Applied Psychology, 89, 1008-1022.

Van Knippenberg, D., \& Schippers, M. C. (2007). Work group diversity. Annual Review of Psychology, 58, 515-541.

Walter, F., \& Bruch, H. (in press). Structural impacts on the occurrence and effectiveness of transformational leadership: An empirical study at the organizational level of analysis. Leadership Quarterly.

Wegge, J., Roth, C., Neubach, B., Schmidt, K. H., \& Kanfer, R. (2008). Age and gender diversity as determinants of performance and health in a public organization: The role of task complexity and group size. Journal of Applied Psychology, 93, 1301-1313.

Williams, K. Y., \& O'Reilly, C. A. (1998). Demography and diversity in organizations: A review of 40 years of research. In B. Staw \& R. Sutton (Eds.), Research in organizational behavior (Vol. 20, pp. 77-140). Greenwich, CT: JAI Press.

Wit, A. P., \& Kerr, N. L. (2002). "Me versus just us versus us all”: Categorization and cooperation in nested social dilemmas. Journal of Personality and Social Psychology, 83, 616-637.

Yukl, G. (2002). Leadership in organizations. Upper Saddle River, NJ: Prentice-Hall.

\section{Bios}

Florian Kunze is a research associate at the University of St. Gallen, Switzerland. His current research interests include consequences of the demographic change for companies, within-group processes and dynamics in work teams and organizations, discrimination and stereotyping because of demographic characteristics, and leadership research.

Heike Bruch is a professor of leadership and director of the Institute for Leadership and Human Resource Management at the University of St. Gallen, Switzerland. Her research interests include organizational energy, leaders' action, emotions in organizations, as well as team and organization processes triggered by diversity. 